\title{
Effects of Dietary Excess Amino Acids on the Concentrations of Cholesterol, $a$-Tocopherol, Ascorbic Acid, and Copper in Serum and Tissues of Rats
}

\author{
Tetsuyuki Katayama, Junko HaYASHI, Masato KISHIDA, \\ and Norihisa KATO ${ }^{1, *}$ \\ Department of Applied Biochemistry, Faculty of Applied Biological Science, \\ Hiroshima University, Saijo, Higashi-Hiroshima 724, Japan
}

(Received May 7, 1990)

\begin{abstract}
Summary An experiment was conducted with growing rats to investigate the effects of feeding excessive specific L-amino acids for 8 days on serum and tissue cholesterol, $\alpha$-tocopherol, ascorbic acid, and copper, and on liver microsomal cytochrome P-450. To a $10 \%$ casein diet were added 4\% L-methionine, 5\% L-cystine, 5\% L-histidine, 5\% L-threonine, 5\% L-tryptophan, 5\% L-phenylalanine, 5\% L-tyrosine, 6\% L-valine, 7\% L-isoleucine, 7\% L-lysine, or 8\% L-leucine. Excessive cystine and histidine increased serum cholesterol and $\alpha$-tocopherol. Excessive cystine and methionine increased liver and kidney $\alpha$-tocopherol and ascorbic acid. Excessive tyrosine and phenylalanine caused a marked increase in serum copper and ceruloplasmin activity, whereas excessive cystine, methionine, and histidine caused a decrease in the ceruloplasmin activity. Excessive histidine increased liver cytochrome P-450, whereas excessive tyrosine markedly decreased liver cytochrome P-450.
\end{abstract}

Key Words dietary excess amino acids, cholesterol, $\alpha$-tocopherol, ascorbic acid, copper, cytochrome P-450

Some inducers of drug-metabolizing enzymes, or xenobiotics including polychlorinated biphenyls (PCB), 1,1,1 -trichloro- 2,2 bis ( $p$-chlorophenyl) ethane (DDT), and Chloretone, cause an increase in serum cholesterol $(1,2)$. These effects are attributed to the stimulation of hepatic cholesterogenesis $(3,4)$. Previous studies by our group and others demonstrated that feeding these xenobiotics causes not only hypercholesterolemia, but also an increase in serum $\alpha$-tocopherol and copper (or ceruloplasmin activity) and tissue and urinary ascorbic acid in rats $(2,5-8)$. These metabolic changes seem to be part of a protective response against xenobiotics (9-12). Recently, we further showed that serum cholesterol positively

1 片山徹之, 林, 順子, 岸田真人, 加藤範久

* To whom reprint requests should be addressed. 
correlates with serum $\alpha$-tocopherol, copper, urinary ascorbic acid, and the activity of drug-metabolizing enzymes in rats fed xenobiotics $(2,6)$. These observations may imply an interrelationship between the changes in cholesterol metabolism and those in the other metabolism mentioned above in rats fed xenobiotics. It is of interest to examine whether hypercholesterolemia caused by some other dietary manipulation is also accompanied by an increase in serum and tissue levels of vitamin $\mathrm{C}$, vitamin $\mathrm{E}$, and copper, and in the activity of liver drug-metabolizing enzymes. Since excessive dietary L-cystine and L-histidine are known to induce hypercholesterolemia by increased cholesterogenesis (13-16), an attempt was made here to examine the influence of excessive dietary cystine and histidine on the metabolism of vitamin $\mathrm{C}$, vitamin $\mathrm{E}$, and copper in rats.

A number of studies have investigated the toxic effects of excess dietary amino acids (17-19). However, only limited data are available concerning the influence of excessive dietary amino acids on the metabolism of other nutritive factors such as minerals and vitamins. Klavins et al. (20) and Yokota et al. (21) reported that excessive dietary L-methionine causes an increase in splenic and liver iron, and anemia in rats. Recently, Harvey et al. (22) demonstrated that excessive dietary L-histidine reduced plasma and liver copper in rats.

Thus, in the present study, we investigated the effects of various excessive dietary amino acids including cystine and histidine on the concentrations of cholesterol, $\alpha$-tocopherol, ascorbic acid, and copper in serum and tissues, and on liver microsomal cytochrome P-450 in rats.

\section{MATERIALS AND METHODS}

Animals and diets. Male rats of the Wistar strain weighing $61-75 \mathrm{~g}$ (Hiro-

Table 1. Composition of diets.

\begin{tabular}{|c|c|c|c|c|c|c|}
\hline \multirow[b]{2}{*}{ Component } & \multicolumn{6}{|c|}{ Amount (\%) } \\
\hline & 10\% Casein & 4\% Met & $\begin{array}{l}5 \% \text { Cys-cys, His, Thr, } \\
\text { Trp, Phe or Tyr }\end{array}$ & $6 \% \mathrm{Val}$ & $\begin{array}{l}7 \% \text { Ile } \\
\text { or Lys }\end{array}$ & $8 \%$ Leu \\
\hline Casein & 10 & 10 & 10 & 10 & 10 & 10 \\
\hline$\alpha$-Corn starch & 50 & 48 & 47 & 46 & 46 & 45 \\
\hline Sucrose & 25 & 23 & 23 & 23 & 22 & 22 \\
\hline Cellulose powder & 4 & 4 & 4 & 4 & 4 & 4 \\
\hline Corn oil & 5 & 5 & 5 & 5 & 5 & 5 \\
\hline Vitamin mixture & 2 & 2 & 2 & 2 & 2 & 2 \\
\hline Salt mixture ${ }^{2}$ & 4 & 4 & 4 & 4 & 4 & 4 \\
\hline Amino acid $^{3}$ & 0 & 4 & 5 & 6 & 7 & 8 \\
\hline
\end{tabular}

${ }^{1}$ Oriental Yeast, Tokyo; Katayama T. et al. (1991): J. Nutr. Biochem., 2, in press.

${ }^{2}$ Ebihara, K. et al. (1979): J. Nutr., 109, 2106. ${ }^{3}$ Met, methionine; Cys-cys, cystine; His, histidine; Thr, threonine; Trp, tryptophan; Phe, phenylalanine; Tyr, tyrosine; Val, valine; Ile, isoleucine; Lys, lysine; Leu, leucine. 
shima Laboratory Animal Center, Hiroshima) were initially fed a stock diet (MF, Oriental Yeast, Tokyo) for 3 to 5 days. These rats were divided into twelve groups of 5 to 6 rats each and fed the test diets (Table 1) for 8 days. Amino acids used for dietary addition were all L-isomers (free base). L-Tyrosine was purchased from Nacalai Tesque, Kyoto, and the other amino acids were purchased from Katayama Chemical, Osaka. The dietary addition of amino acid was made at the expense of the carbohydrate composed of one part of sucrose and two parts of $\alpha$-corn starch. All the diets and deionized water were supplied ad libitum. Room temperature was kept at $24 \pm 1{ }^{\circ} \mathrm{C}$ with 12 -h cycle of light $(8: 00$ a.m. $-8: 00$ p.m.) and dark. After feeding them for 8 days, the diets were removed from cages at 8:00 a.m.; the animals were lightly anesthetized with ether and killed between 1:00 p.m. and 3:00 p.m. Blood was collected by heart puncture and serum samples were isolated by centrifugation at $4^{\circ} \mathrm{C}$. Liver and kidney were immediately excised and weighed.

Liver microsomal cytochrome P-450. Liver homogenate $(9.1 \% \mathrm{w} / \mathrm{v})$ was prepared with ice-cold $0.25 \mathrm{M}$ sucrose containing $10 \mathrm{mM}$ Tris-chloride, $\mathrm{pH}$ 7.4. The homogenate was centrifuged to obtain the postmitochondrial supernatant $(12,000$ $\times g, 15 \mathrm{~min}$ at $\left.4^{\circ} \mathrm{C}\right)$. Addition of solid $\mathrm{CaCl}_{2}(8.0 \mathrm{mM}$ final concentration) to the postmitochondrial supernatant allowed complete sedimentation of the microsomes at $25,000 \times g$ for $15 \mathrm{~min}\left(4^{\circ} \mathrm{C}\right)(23)$. The pellet was suspended in $0.05 \mathrm{M}$ phosphate buffer, $\mathrm{pH}$ 7.6, containing $10 \mathrm{mM}$ EDTA, and assayed for microsomal protein and cytochrome P-450.

Analytical procedures. Microsomal cytochrome P-450 content was determined by the dithionite difference method of Omura and Sato (24). Microsomal protein was determined by the procedure of Miller with bovine serum albumin as a standard (25). Tissues were homogenized with ice-cold 5\% metaphosphoric acid and centrifuged for $10 \mathrm{~min}$ at $1,600 \times g$. Ascorbic acid in the supernatant was measured by the dinitrophenylhydrazine method (26). Serum and tissue $\alpha$ tocopherol was measured by HPLC method described previously (12). Serum cholesterol was measured by the method of Pearson et al. (27). Liver cholesterol was extracted by the method of Folch et al. (28). A portion of this extract was dried; the cholesterol content of the tissue was measured by the method of Pearson et al.(27). Serum and liver contents of copper were measured by a polarized Zeeman atomic absorption spectrophotometer (29). The activity of serum ceruloplasmin [EC 1.16.3.1.] was determined by the method of Schosinsky et al. (30), in which $o$-dianisidine dihydrochloride was used as a substrate.

Statistical analysis. Statistical significance of differences between values was analyzed by analysis of variance (ANOVA) and Duncan's multiple-range test (31).

\section{RESULTS}

As shown in Table 2, food intake was significantly depressed in rats fed diets excessive in the amino acids tested except for the cystine-, lysine-, and valineexcessive diets. In addition, excess histidine, methionine, threonine, tryptophan, 
Table 2. Food intake, growth, and organ weights of rats fed diets excessive in single amino acids. ${ }^{1}$

\begin{tabular}{lcccc}
\hline \multicolumn{1}{c}{ Diets } & $\begin{array}{c}\text { Food intake } \\
\text { (g/day) }\end{array}$ & $\begin{array}{c}\text { Gains in body wt. } \\
\text { (g/8 days) }\end{array}$ & $\begin{array}{c}\text { Liver wt. } \\
\text { (\% of body wt.) }\end{array}$ & $\begin{array}{c}\text { Kidney wt. } \\
\text { (\% of body wt.) }\end{array}$ \\
\hline 10\% Casein & $8.4 \pm 0.3^{\mathrm{a3}}$ & $4.2 \pm 1.4^{\mathrm{a}}$ & $4.33 \pm 0.19^{\mathrm{ab}}$ & $0.91 \pm 0.01^{\mathrm{a}}$ \\
5\% Cystine & $8.3 \pm 0.7^{\mathrm{a}}$ & $0.8 \pm 5.2^{\mathrm{ab}}$ & $4.49 \pm 0.20^{\mathrm{ac}}$ & $1.20 \pm 0.04^{\mathrm{b}}$ \\
$5 \%$ Histidine & $3.8 \pm 0.2^{\mathrm{b}}$ & $-17.9 \pm 1.1^{\mathrm{de}}$ & $5.10 \pm 0.17^{\mathrm{c}}$ & $1.20 \pm 0.02^{\mathrm{b}}$ \\
4\% Methionine & $4.0 \pm 0.2^{\mathrm{b}}$ & $-18.5 \pm 2.0^{\mathrm{e}}$ & $4.09 \pm 0.22^{\mathrm{abd}}$ & $1.37 \pm 0.03^{\mathrm{c}}$ \\
5\% Threonine & $4.8 \pm 0.3^{\mathrm{bc}}$ & $-9.5 \pm 2.1^{\mathrm{cd}}$ & $4.21 \pm 0.20^{\mathrm{ab}}$ & $1.12 \pm 0.05^{\mathrm{b}}$ \\
8\% Leucine & $6.5 \pm 0.7^{\mathrm{de}}$ & $-1.8 \pm 1.6^{\mathrm{ab}}$ & $3.87 \pm 0.22^{\mathrm{abd}}$ & $0.91 \pm 0.04^{\mathrm{a}}$ \\
7\% Isoleucine & $6.5 \pm 0.7^{\mathrm{de}}$ & $-2.8 \pm 2.9^{\mathrm{abc}}$ & $3.54 \pm 0.10^{\mathrm{d}}$ & $0.89 \pm 0.02^{\mathrm{a}}$ \\
7\% Lysine & $7.1 \pm 0.6^{\mathrm{ae}}$ & $-3.6 \pm 2.8^{\mathrm{abc}}$ & $4.49 \pm 0.14^{\mathrm{ac}}$ & $0.93 \pm 0.03^{\mathrm{ad}}$ \\
6\% Valine & $7.4 \pm 0.2^{\mathrm{ae}}$ & $-3.0 \pm 0.4^{\mathrm{abc}}$ & $3.74 \pm 0.07^{\mathrm{bd}}$ & $0.96 \pm 0.04^{\mathrm{ad}}$ \\
5\% Tryptophan & $5.9 \pm 0.5^{\mathrm{cde}}$ & $-15.0 \pm 1.3^{\mathrm{de}}$ & $3.55 \pm 0.13^{\mathrm{d}}$ & $1.07 \pm 0.02^{\mathrm{bd}}$ \\
5\% Phenylalanine & $5.1 \pm 0.3^{\mathrm{bd}}$ & $-14.0 \pm 2.5^{\mathrm{de}}$ & $4.09 \pm 0.20^{\mathrm{abd}}$ & $1.12 \pm 0.05^{\mathrm{b}}$ \\
5\% Tyrosine & $6.3 \pm 0.5^{\mathrm{de}}$ & $-12.3 \pm 1.3^{\mathrm{de}}$ & $3.47 \pm 0.35^{\mathrm{d}}$ & $1.38 \pm 0.11^{\mathrm{c}}$ \\
\hline
\end{tabular}

${ }^{1}$ Initial body weight average, $64 \mathrm{~g}$ (59-73 g); feeding period, 8 days. ${ }^{2}$ On days 4-6.

${ }^{3}$ Values represent mean \pm SE of 5 to 6 rats. Means not followed by the same letter are significantly different $(p<0.05)$.

phenylalanine, and tyrosine caused a significant depression in growth. The growth rate was directly related to food intake $(r=0.87, p<0.05)$. Liver weight $(\%$ of body wt.) was increased by excessive histidine diet, and decreased by the excessive isoleucine, valine, and tryptophan diets. Kidney weight ( $\%$ of body wt.) was increased by the excessive cystine, histidine, methionine, threonine, tryptophan, phenylalanine, and tyrosine diets (Table 2).

As shown in Fig. 1, A and B, excessive cystine and histidine raised serum cholesterol (average increase of $101 \%$ in rats fed excessive cystine and $31 \%$ in rats fed excessive histidine) and $\alpha$-tocopherol (average increase of $92 \%$ in rats fed excessive cystine and 43\% in rats fed excessive histidine). Figures 1, C and D show the effect of excessive dietary amino acids on serum ceruloplasmin activity and copper. In general, the effects of excess dietary amino acids on serum ceruloplasmin activity or copper, and on serum cholesterol or $\alpha$-tocopherol were inversely related (Fig. 1, A and B). Excessive phenylalanine and tyrosine caused a marked increase in serum ceruloplasmin activity (average increase of $78 \%$ with excessive phenylalanine and $134 \%$ with excessive tyrosine) and copper (average increase of $67 \%$ with excessive phenylalanine and 155\% with excessive tyrosine) (Fig. 1, C and D). Serum ceruloplasmin activity was significantly decreased by excessive cystine, histidine, and methionine. There was a tendency for decreased serum copper in rats fed excessive histidine or methionine.

As shown in Fig. 2, A and B, excessive dietary cystine and methionine increased liver $\alpha$-tocopherol (average increase 61\% with excessive cystine and $56 \%$ with excessive methionine) and ascorbic acid (average increase $102 \%$ with exces- 

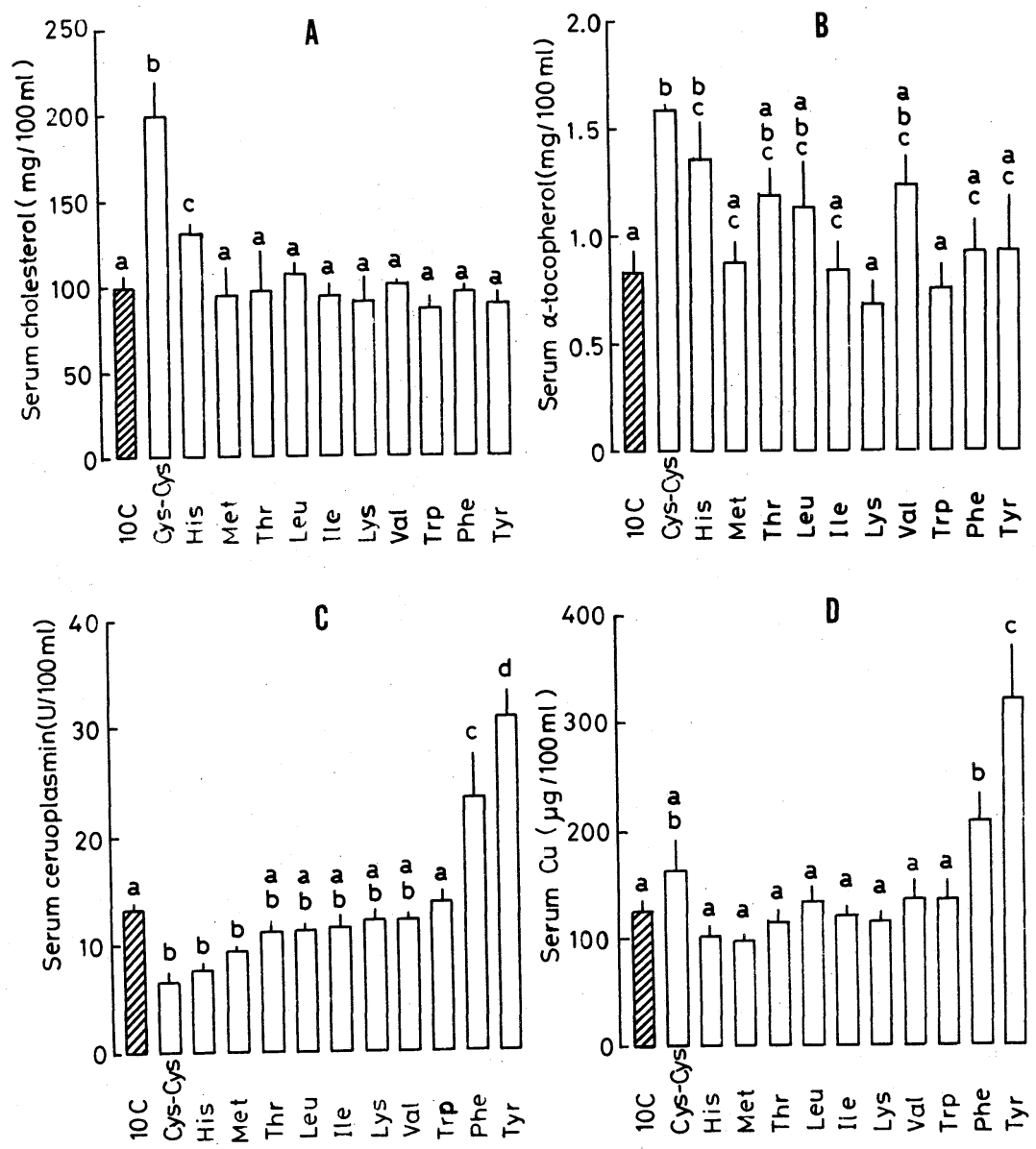

Fig. 1. Effects of excessive dietary amino acids on serum cholesterol, $\alpha$-tocopherol, ceruloplasmin activity, and copper in rats. (A) Serum cholesterol; (B) Serum $\alpha$-tocopherol; (C) Serum ceruloplasmin activity; (D) Serum copper. Each bar indicates mean \pm SE. Means not followed by the same letter are significantly different $(p<0.05)$. 10C, 10\% casein diet without addition of amino acid.

sive cystine and $32 \%$ with excessive methionine). In addition, kidney ascorbic acid was also increased by excessive cystine and methionine (Fig. 3). Excessive histidine significantly decreased liver ascorbic acid, but not kidney ascorbic acid. Excessive phenylalanine increased kidney ascorbic acid, although this increment was slight (Fig. 3). In addition to serum cholesterol, hepatic cholesterol was increased by excessive dietary cystine (Fig. 2C). Liver copper was also significantly increased by excessive cystine (Fig. 2D).

Table 3 shows the influence of excess amino acids on liver microsomal cytochrome P-450. The contents of liver microsomal cytochrome P-450 was expressed per mg protein and per $100 \mathrm{~g}$ body weight. Excessive tyrosine markedly 

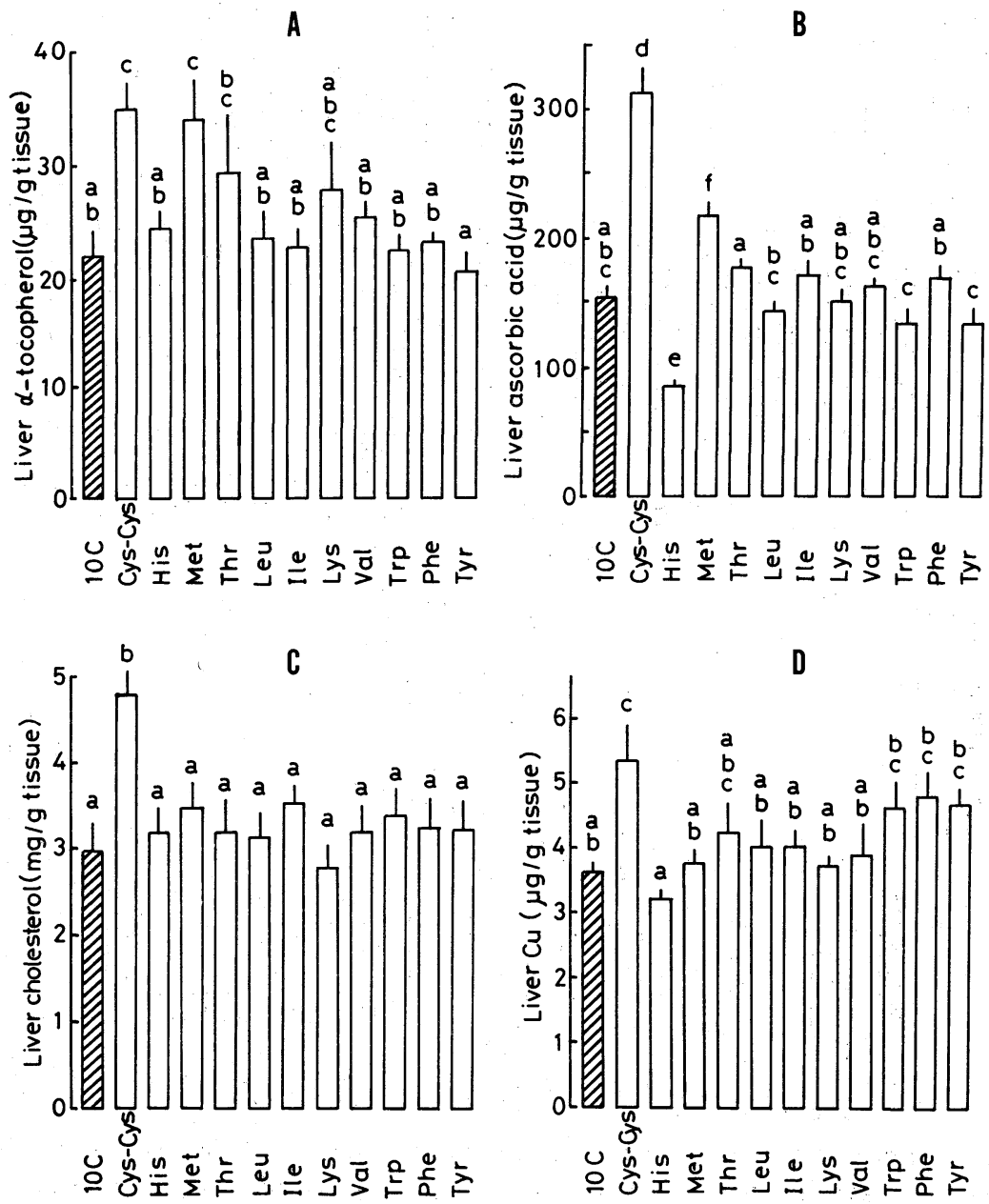

Fig. 2. Effects of excessive dietary amino acids on liver $\alpha$-tocopherol, ascorbic acid, cholesterol, and copper in rats. (A) Liver $\alpha$-tocopherol; (B) Liver ascorbic acid; (C) Liver cholesterol; (D) Liver copper. Each bar indicates mean $\pm \mathrm{SE}$. Means not followed by the same letter are significantly different $(p<0.05) .10 \mathrm{C}$, $10 \%$ casein diet without addition of amino acid.

depressed the content of liver microsomal cytochrome P-450 expressed in per mg protein or in per $100 \mathrm{~g}$ body weight. Excessive histidine significantly increased the content of liver cytochrome P-450 when expressed as the percent of body weight (Table 3).

In this experiment, serum cholesterol significantly $(p<0.05)$ correlated with serum $\alpha$-tocopherol $(r=0.42)$, liver ascorbic acid $(r=0.50)$, kidney ascorbic acid $(r=0.36)$, and liver cholesterol $(r=0.50)$, but not $(p>0.05)$ with liver $\alpha$ tocopherol $(r=0.25)$, liver copper $(r=-0.07)$, and serum copper $(r=-0.11)$. 


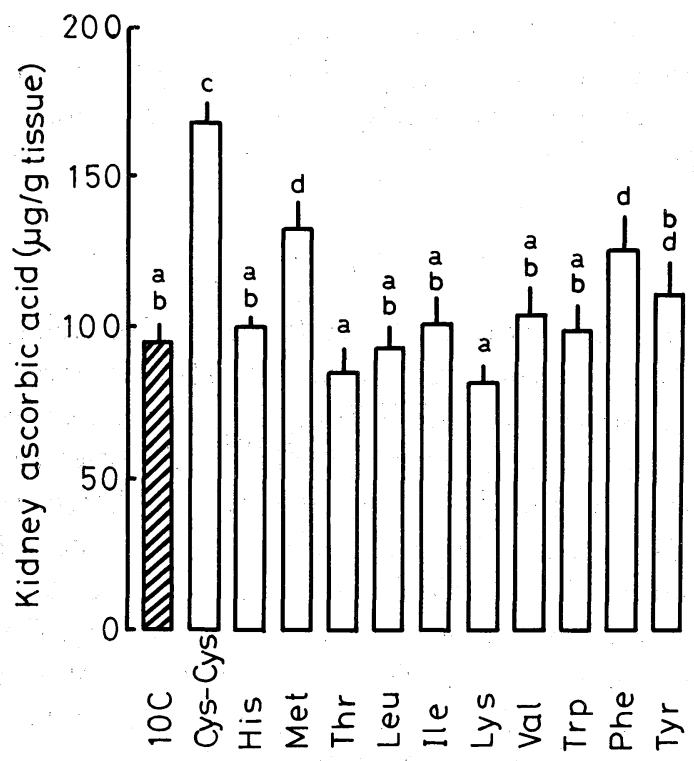

Fig. 3. Effect of excessive dietary amino acids on kidney ascorbic acid in rats. Each bar indicates mean $\pm \mathrm{SE}$. Means not followed by the same letter are significantly different $(p<0.05) .10 \mathrm{C}, 10 \%$ casein diet without addition of amino acid.

Table 3. Liver microsomal protein and P-450 content of rats fed diets excessive in single amino acids.

\begin{tabular}{|c|c|c|c|}
\hline \multirow{3}{*}{ Diets } & \multicolumn{3}{|c|}{ Liver microsomal parameters } \\
\hline & \multirow{2}{*}{$\begin{array}{c}\text { Protein } \\
\text { (mg/g liver) }\end{array}$} & \multicolumn{2}{|c|}{ Cytochrome P- 450} \\
\hline & & (pmol/mg protein) & (nmol/100 g body) \\
\hline 10\% Casein & $17.8 \pm 1.9^{1, \mathrm{a}}$ & $391 \pm 20^{\mathrm{ab}}$ & $29.1 \pm 3.7^{\mathrm{a}}$ \\
\hline 5\% Cystine & $21.6 \pm 1.0^{\mathrm{a}}$ & $350 \pm 58^{a}$ & $33.7 \pm 5.6^{\mathrm{a}}$ \\
\hline 5\% Histidine & $19.3 \pm 1.3^{\mathrm{a}}$ & $501 \pm 30^{b}$ & $48.5 \pm 2.4^{b}$ \\
\hline 4\% Methionine & $21.4 \pm 0.7^{\mathrm{a}}$ & $470 \pm 43^{\mathrm{ab}}$ & $40.7 \pm 3.4^{a b}$ \\
\hline 5\% Threonine & $21.0 \pm 0.7^{\mathrm{a}}$ & $404 \pm 44^{\mathrm{ab}}$ & $35.5 \pm 4.1^{\mathrm{a}}$ \\
\hline $8 \%$ Leucine & $19.3 \pm 1.3^{\mathrm{a}}$ & $442 \pm 39^{\mathrm{ab}}$ & $32.9 \pm 3.7^{\mathrm{a}}$ \\
\hline $7 \%$ Isoleucine & $21.9 \pm 1.0^{\mathrm{a}}$ & $409 \pm 36^{\mathrm{ab}}$ & $28.8 \pm 1.0^{\mathrm{a}}$ \\
\hline 7\% Lysine & $18.8 \pm 1.9^{\mathrm{a}}$ & $382 \pm 93^{\mathrm{ab}}$ & $28.4 \pm 6.3^{\mathrm{a}}$ \\
\hline $6 \%$ Valine & $21.1 \pm 1.3^{\mathrm{a}}$ & $405 \pm 42^{\mathrm{ab}}$ & $32.6 \pm 3.2^{\mathrm{a}}$ \\
\hline 5\% Tryptophan & $21.7 \pm 1.7^{\mathrm{a}}$ & $438 \pm 26^{\mathrm{ab}}$ & $33.2 \pm 2.7^{\mathrm{a}}$ \\
\hline 5\% Phenylalanine & $20.8 \pm 1.9^{\mathrm{a}}$ & $393 \pm 13^{\mathrm{ab}}$ & $33.6 \pm 3.9^{\mathrm{a}}$ \\
\hline $5 \%$ Tyrosine & $20.5 \pm 1.9^{\mathrm{a}}$ & $164 \pm 26^{c}$ & $17.1 \pm 2.1^{\mathrm{c}}$ \\
\hline
\end{tabular}

${ }^{1}$ Values represent mean $\pm \mathrm{SE}$ of 5 to 6 rats. Means not followed by the same letter are significantly different $(p<0.05)$. 
Liver microsomal cytochrome P-450 positively correlated with serum cholesterol when expressed as per $100 \mathrm{~g}$ body weight $(r=0.29, p<0.05)$, but not per mg protein $(r=-0.043, p>0.05)$. Serum cholesterol negatively correlated with serum ceruloplasmin activity $(r=-0.34, p<0.05)$.

\section{DISCUSSION}

The results presented here demonstrated that excessive dietary cystine induced not only an increase in serum cholesterol, but also an increase in serum $\alpha$ tocopherol and tissue ascorbic acid in rats (Figs. 1-3). These metabolic responses are similar to those in rats fed xenobiotics. Excessive dietary methionine also slightly raised tissue $\alpha$-tocopherol and ascorbic acid, although serum cholesterol was not influenced (Figs. 2 and 3). Kato et al. (32) and Oda et al. (33) reported that the supplementation of $0.3-1.5 \%$ cystine or methionine to a $10 \%$ soy protein diet markedly increased urinary ascorbic acid in rats fed PCB. Recently, we showed that dietary level of cystine positively correlated with serum $\alpha$-tocopherol and tissue ascorbic acid in rats fed a 10 or $25 \%$ casein diet supplemented with $0.3-$ 5\% cystine (Kato and Katayama, to be published). These findings, together with those from the present study, suggest that sulfur-containing amino acids have a key role in the metabolism of vitamin $\mathrm{C}$ and vitamin $\mathrm{E}$. It has already been elucidated that the increments in serum cholesterol, tissue ascorbic acid, and serum $\alpha$ tocopherol by xenobiotics are the result of increased biosynthesis of cholesterol and ascorbic acid $(3,4,8)$ and increased intestinal absorption of $\alpha$-tocopherol (34). Further studies are in progress to examine the mechanisms of the metabolic responses of vitamin $\mathrm{C}$ and vitamin $\mathrm{E}$ to excessive cystine.

In addition to excessive cystine, excessive histidine increased serum cholesterol and $\alpha$-tocopherol (Fig. 1). There was a correlation between serum cholesterol and $\alpha$-tocopherol in the present experiment. These facts are in agreement with the reported general correlation between serum cholesterol and $\alpha$-tocopherol in rats or humans under several dietary conditions $(35,36)$.

Of interest was the observation that excessive dietary tyrosine and phenylalanine markedly increased serum copper and ceruloplasmin activity (Fig. 1). Recently, we demonstrated that intestinal copper absorption is increased by excessive dietary tyrosine and phenylalanine (Kishida and Kato, to be published). Further studies are necessary on the physiological significance of these effects and the requirement of copper for animals fed excessive tyrosine or phenylalanine in the diet.

Excessive dietary cystine and methionine decreased serum ceruloplasmin activity (Fig. 1). It has been reported that excessive dietary methionine induces anemia and increases liver iron in rats $(20,21)$. Klavins et al. (20) showed that the changes in tissue iron caused by excessive methionine in the diet can be explained by a shift in body iron. One of the physiological effects of ceruloplasmin activity is related to the conversion of iron (II) to iron (III) prior to its incorporation into 
transferrin (37). Therefore, the changes in tissue iron caused by excess dietary methionine may be partly mediated through a decreased ceruloplasmin activity. Recently, Nielsen showed that feeding diets high in sulfur amino acids potentiate the severity of signs of copper deficiency in rats (38) and human (39). These observations imply that dietary sulfur-containing amino acids can influence copper status in animals.

Excessive histidine caused liver enlargement and an increased liver microsomal cytochrome P-450 when expressed as per $100 \mathrm{~g}$ body weight (Tables 2 and 3). This liver enlargement is in agreement with the results of experiments by Harvey et al. (22). Interestingly, dietary excess tyrosine severely depressed liver microsomal cytochrome P-450. We previously reported that increasing dietary level or quality of protein raises the activities of drug-metabolizing enzymes and microsomal cytochrome P-450 in liver $(40,41)$. The present findings suggest that dietary excessive histidine and tyrosine specifically affect liver drug-metabolizing enzyme systems.

In the present study, $4-8 \%$ of amino acids were added to the $10 \%$ casein diet to examine the influence of excess amino acids. Further study is in progress to determine the dietary levels of amino acids required for the changes in the metabolic parameters examined here.

The authors wish to express their sincere thanks to Professor A. Yoshida, Nagoya University, and Dr. F. H. Nielsen, Grand Forks Human Nutrition Research Center, for their comments regarding preparation of this manuscript.

\section{REFERENCES}

1) Kato, N., and Yoshida, A. (1979): Effects of some fat-soluble chemicals on plasma cholesterol and urinary ascorbic acid in rats. Agric. Biol. Chem., 43, 191-192.

2) Kato, N., and Yoshida, A. (1981): Effect of various dietary xenobiotics on serum total cholesterol and high density lipoprotein cholesterol in rats. Nutr. Rep. Int., 23, 825831.

3) Kato, N., and Yoshida, A. (1980): Effect of dietary PCB on hepatic cholesterogenesis in rats. Nutr. Rep. Int., 21, 107-112.

4) Nagaoka, S., Masaki, H., Aoyama, Y., and Yoshida, A. (1986): Effects of excess dietary tyrosine or certain xenobiotics on the cholesterogenesis in rats. J. Nutr., 116, 726-732.

5) Innami, S., Ikegami, S., Saito, M., Nakamura, A., and Nagayama, S. (1982): Lack of responsibility of lipid peroxidation for reduction of vitamin A in the liver of rats given polychlorinated biphenyls. Nutr. Rep. Int., 25, 931-940.

6) Ohchi, H., Kusuhara, T., Katayama, T., Ohara, K., and Kato, N. (1987): Effects of dietary xenobiotics on the metabolism of copper, $\alpha$-tocopherol and cholesterol in rats. J. Nutr. Sci. Vitaminol., 33, 281-288.

7) Kato, N., Kishida, M., and Ohara, K. (1988): Effect of dietary addition of PCB on copper status in rats. Nutr. Rep. Int., 38, 1081-1089. 
8) Horio, F., and Yoshida, A. (1982): Effects of some xenobiotics on ascorbic acid metabolism in rats. J. Nutr., 112, 416-425.

9) Kawai-Kobayashi, K., and Yoshida, A. (1986): Effect of dietary ascorbic acid and vitamin $\mathrm{E}$ on metabolic changes in rats and guinea pigs exposed to PCB. J. Nutr., 116, 98-116.

10) Kato, N., Okada, T., Takenaka, Y., and Yoshida, A. (1977): Ameliorative effect of dietary ascorbic acid on PCB toxicity in guinea pigs. Nutr. Rep. Int., 15, 125-130.

11) Kato, N., Kawai, K., and Yoshida, A. (1981): Effect of dietary level of ascorbic acid on the growth, hepatic lipid peroxidation, and serum lipids in guinea pigs fed polychlorinated biphenyls. J. Nutr., 111, 1727-1733.

12) Katayama, T., Ohara, K., Kusuhara, T., Momota, Y., and Kato, N. (1989): Influence of copper deficient diet on the metabolic changes in rats exposed to PCB. Nutr. Rep. Int., 39, 963-971.

13) Serougne, C., Ferezou, J., and Rukaj, A. (1984): Effects of excess dietary L-cystine on the rat plasma lipoproteins. Annu. Nutr. Metab., 28, 311-320.

14) Aoyama, Y., Matsumoto, H., Tsuda, T., Ohmura, E., and Yoshida, A. (1988): Effect on liver and serum lipids in rats of dietary additions of fibers and cholestyramine to a cystine-excess diet. Agric. Biol. Chem., 52, 2811-2816.

15) Solomon, J. K., and Geison, R. L. (1978): L-Histidine-induced hypercholesterolemia: Characteristics of cholesterol biosynthesis in rat livers. Proc. Soc. Exp. Biol. Med., 159, 44-47.

16) Ohmura, E., Aoyama, Y., and Yoshida, A. (1986): Changes in lipids in liver and serum of rats fed a histidine-excess diet or cholesterol-supplemented diets. Lipids, 21, 748-753.

17) Benevenga, N. J., Yeh, M.-H., and Lalich, J. J. (1976): Growth depression and tissue reaction to the consumption of excess dietary methionine and S-methyl-L-cysteine. $J$. Nutr., 106, 1714-1720.

18) Boctor, A. M., and Harper, A. E. (1968): Tyrosine toxicity in the rat: Effect of high intake of $p$-hydroxyphenylpyruvic acid and of force-feeding high tyrosine diet. $J$. Nutr., 95, 535-540.

19) Daniel, R. G., and Waisman, H. A. (1968): The effects of excess amino acids on the growth of the young rat. Growth, 32, 255-265.

20) Klavins, J. V., Kinney, J. D., and Kaufman, N. (1963): Body iron levels and hematologic finds during excess methionine feeding. J. Nutr., 79, 101-104.

21) Yokota, F., Esashi, T., and Suzue, R. (1978): Nutritional anemia induced by excess methionine in rat and the alleviative effects of glycine on it. J. Nutr. Sci. Vitaminol., 24, 527-533.

22) Harvey, P. W., Hunsaker, H. A., and Allen, K. G. D. (1981): Dietary L-histidineinduced hypercholesterolemia and hypocupremia in the rat. J. Nutr., 111, 639-647.

23) Katayama, T., Momota, Y., Kanbara, M., and Kato, N. (1988): Effects of dietary xenobiotics and protein level on hepatic microsomal and cytosol cholesterol in rats. Nutr. Rep. Int., 37, 745-753.

24) Omura, T., and Sato, R. (1964): The carbon monoxide-binding pigment of liver microsomes. J. Biol. Chem., 239, 2370-2378.

25) Miller, G. L. (1959): Protein determination for large numbers of samples. Anal. Chem., 31, 964. 
26) Ohara, T. (1973): Shokuhinbunseki Handbook (in Japanese), Kenpaku, Tokyo, pp. 301-305.

27) Pearson, S., Sterm, S., and McGavack, T. H. (1953): A rapid, accurate method for the determination of total cholesterol in serum. Anal. Chem., 25, 813-814.

28) Folch, J., Lees, M., and Sloane-Stanley, G. H. (1957): A simple method for the isolation and purification of total lipides from animal tissues. J. Biol. Chem., 226, 497509.

29) Gunshin, H., Yoshikawa, M., Doudou, T., and Kato, N. (1985): Trace elements in human milk, cow's milk and infant formula. Agric. Biol. Chem., 49, 21-26.

30) Schosinsky, K. H., Lehmann, H. P., and Beeler, M. F. (1974): Measurement of ceruloplasmin from its oxidase activity in serum by use of $o$-dianisidine dihydrochloride. Clin. Chem., 20, 1556-1563.

31) Duncan, D. B. (1957): Multiple-range tests for correlated and heteroscedastic means. Biometrics, 13, 164-176.

32) Kato, N., Mochizuki, S., Kawai, K., and Yoshida, A. (1982): Effect of dietary level of sulfur-containing amino acids on liver drug-metabolizing enzymes, serum cholesterol and urinary ascorbic acid in rats fed PCB. J. Nutr., 112, 848-854.

33) Oda, H., Matsuoka, S., and Yoshida, A. (1986): Effects of dietary methionine, cystine and potassium sulfate on serum cholesterol and urinary ascorbic acid in rats fed PCB. J. Nutr., 116, 1660-1666.

34) Katayama, T., Momota, Y., Watanabe, Y., and Kato, N. (1991): Elevated concentrations of $\alpha$-tocopherol, ascorbic acid and serum lipids in rats fed polychlorinated biphenyls, chlorobutanol or phenobarbital. J. Nutr. Biochem., 2, in press.

35) Desai, I. D., and Lee, M. (1974): Plasma vitamin E and cholesterol relationship in Western Canadian Indians. Am. J. Clin. Nutr., 27, 334-338.

36) Hirai, K., Matsushita, M., Namiki, M., and Hotta-Hara, H. (1988): Effects of various dietary cholesterol levels on serum tocopherol and fatty acid composition in female rats. J. Clin. Biochem. Nutr., 4, 111-118.

37) Williams, D. M., Lee, G. R., and Carturight, G. E. (1974): Ferroxidase activity of rat ceruloplasmin. Am. J. Physiol., 227, 1094-1098.

38) Nielsen, F. H. (1988): Sulfur amino acid nutriture affects the signs of copper deficiency in the rat. J. Trace Elements Exp. Med., 1, 157-166.

39) Nielsen, F. H. (1989): Abstract papers, The 14th International Congress of Nutrition, Korea, Seoul, p. 491.

40) Kato, N., Tani, T., and Yoshida, A. (1980): Effect of dietary level of protein on liver microsomal drug-metabolizing enzymes, urinary ascorbic acid and lipid metabolism in rats fed PCB containing diets. J. Nutr., 110, 1686-1694.

41) Kato, N., Tani, T., and Yoshida, A. (1981): Effect of dietary quality of protein on liver microsomal mixed function oxidase system, plasma cholesterol and urinary ascorbic acid in rats fed PCB. J. Nutr., 111, 123-133. 